\title{
OPTIMISATION OF LACTOSE HYDROLYSIS BY COMBINING SOLIDS AND B-GALACTOSIDASE CONCENTRATIONS IN WHEY PERMEATES
}

\author{
Kristine Majore" and Inga Ciproviča \\ Faculty of Food Technology, Latvia University of Life Sciences and Technologies, 22 Rīgas Str., Jelgava, LV-3004, LATVIA \\ \# Corresponding author, kristiine.majore@gmail.com
}

Contributed by Inga Ciproviča

\begin{abstract}
A detailed study of lactose hydrolysis was conducted using 50, 250 and 500 units of B-galactosidase (Kluyveromyces lactis and Bacillus licheniformis origin) in acid and sweet whey permeates at different solid concentrations $20 \%, 30 \%$ and $40 \%\left(w \cdot v^{-1}\right)$. The amount of lactose, glucose and galactose was measured by HPLC - RID. Hydrolysis was carried out at optimal enzyme temperature $42.5{ }^{\circ} \mathrm{C}$ for $4 \mathrm{~h}$. Medium $\mathrm{pH}$ before hydrolysis was adjusted using $10 \% \mathrm{KOH}$. The experimental results were compared taking into account the sugar profiles and experimental conditions. The highest lactose hydrolysis occurred at solid concentration $20 \%\left(w \cdot v^{-1}\right)$ and at enzyme amounts of 250 and 500 units for both permeates. Using 50 units of enzymes, in many cases the amounts of glucose and galactose were more or less equal in range of 6.5-43 g. $\Gamma^{1}$ and the hydrolysis percentage was quite low in the range of 2.7-62\%. Comparing both whey permeates, a higher hydrolysis percentage (99\%) was obtained using acid whey and 500 enzyme units.
\end{abstract}

Key words: glucose-galactose syrup, enzymatic hydrolysis, commercial lactase.

\section{INTRODUCTION}

More than half of the dairy global facilities treat whey as a waste product that cannot be recycled and transforming into new, high value-added products (Sady et al., 2013). Use of whey was previously underestimated and nowadays is considered as a valuable by-product due to the growing tendency of including valuable components of whey in infant nutrition and as well in dietetic food production (Tanguy et al., 2019). Most often sweet whey is redirected to spray drying to form high-value dairy powders for use in infant formula and sport nutrition applications (Chandrapala et al., 2016). Comparing acid and sweet whey, the content of constituents differs in the concentrations of protein, minerals and lactose, and there are significant differences in the amounts of casein and calcium and acidity (Wronkowska et al., 2018). Both sweet and acid whey have about $94 \%$ water and $4.5 \%$ lactose, while acid whey has higher acidity than sweet whey, with medium $\mathrm{pH} 4.3-5.1$ for acid whey and $\mathrm{pH}$ 5.9-6.6 in sweet whey (Lindsay et al., 2018).

The dairy industry now has a challenge concerning acid whey. During the last five years, the consumer as well as market demands have rapidly raised for a variety of acid-coagulated products (curd, cottage cheese, quark), and it is predicted that this trend will continue globally. Moreover, this situation poses a problem of the creation of 1.6 billion litres per year of acid whey as waste (Chandrapala et al., 2015).

Acid whey contains large amounts of lactic acid and salt, which may influence the properties and behaviour of lactose and other whey components during concentration and processing (Zolnere and Ciprovica, 2019). The impact of acid whey composition on processing has not been well studied, making it difficult to find solutions to the present and growing problem (Chandrapala et al., 2015).

Potentially, a part of the produced whey can be used as a base for new product development. Concentrated whey has many benefits. It is rich in composition and adds nutritional and functional value to products (Argenta and Scheer, 2020). While processing of whey is not competitive against existing fermentation process using sugar cane, corn starch and lignocellulosic biomass as substrates, whey fermenta- 
tion is nowadays a major focus for high-value products (Sampaio et al., 2019).

Whey and whey permeate fermentation without any pretreatment is not profitable due to their low lactose content, which means higher costs. On the other hand, dried or concentrated whey and whey permeate could be used for the production of new sugars, because the water content is low and lactose content is high, and are cheap and can be stored easily (Argenta and Scheer, 2020).

In this study, lactose hydrolysis was performed using multiple-unit amounts of $\beta$-galactosidase (Kluyveromyces lactis and Bacillus licheniformis) in acid and sweet whey permeates at different solid concentrations $(20 \%, 30 \%$, and $40 \%$ $\left.\mathrm{w} \cdot \mathrm{v}^{-1}\right)$. The obtained results can be valuable for dairy facilities that are already producing glucose-galactose syrup or thinking to introduce this process in the near future.

\section{MATERIALS AND METHODS}

Materials. NOLA Fit5500 (NF), a ß-galactosidase soluble preparation from Bacillus licheniformis, and Ha-Lactase 5200 (HL, a ß-galactosidase soluble preparation from Kluyveromyces lactis were obtained from Chr. HANSEN (Denmark). GODO-YNL2 (GY) ß-galactosidase, soluble preparation from Kluyveromyces lactis, was kindly provided by Danisco (Denmark). Acetonitrile (HPLC grade, $\geq 99.93 \%$ purity), column SUPELCOSILTM LC-NH2, (250 $\mathrm{mm} \times 4.6 \mathrm{~mm} \times 5 \mu \mathrm{m})$, D-lactose monohydrate $(\geq 99.5 \%$ purity), $\mathrm{D}(+)$ galactose $(\geq 99 \%$ purity), $\mathrm{D}(+)$ glucose ( $\geq 99.5 \%$ purity) were purchased from Sigma-Aldrich (St. Louis, MO, USA), $\mathrm{KOH} \mathrm{(} \geq 85 \%$, pellets) was purchased from EMSURE (Germany). Sweet whey permeate was donated by SC "Smiltenes piens", and acid whey permeate from SC "Tukuma piens". All reagents and solvents were of the highest available purity and used as purchased.

Determination of permeate content. Lactose, protein, fat and total solids contents were determined before solids concentration using a MilkoScan ${ }^{\mathrm{TM}}$ Mars, Foss Analytical SC (Denmark). Medium $\mathrm{pH}$ was determined with a $\mathrm{pH}$-meter $720 \mathrm{pH}$ meter (WTW, the Netherlands).

Solids concentration. Permeates with $20 \%\left(\mathrm{w} \cdot \mathrm{v}^{-1}\right), 30 \%$ $\left(\mathrm{w} \cdot \mathrm{v}^{-1}\right)$ and $40 \%\left(\mathrm{w} \cdot \mathrm{v}^{-1}\right)$ of solids concentration were ob- tained, as previously described (Zolnere and Ciprovica, 2019).

Enzymatic hydrolysis of permeates. Lactose hydrolysis was performed as described previously (Zolnere and Ciprovica, 2019) with some modification. The hydrolysis of lactose in permeates was carried out by varying amounts of commercial enzymes (Table 1) added to $50 \mathrm{ml}$ permeate. Permeates were kept in a thermostat (Memmert IN55, Germany) at temperature $42.5^{\circ} \mathrm{C}$ for $4 \mathrm{~h}$. The main properties of commercial enzymes used in the study are summarised in Table 2. $\mathrm{pH}$ was adjusted with $10 \% \mathrm{KOH}$ solution prior to hydrolysis, for HL enzyme in the $\mathrm{pH}$ range of 6.5-6.6, for NF enzyme pH 5.4-5.6 and GY enzyme pH 7.5-7.6. Triplicate experiments were prepared for each type of permeate. After fermentation, samples were placed in a water bath at $90{ }^{\circ} \mathrm{C}$ for $5 \mathrm{~min}$. Samples were transferred into $50 \mathrm{ml}$ test tubes and placed in a freezer at $-18{ }^{\circ} \mathrm{C}$ for further measurements.

The degree of lactose hydrolysis was calculated by the following equation:

$$
H(\%)=\frac{L_{0}-L_{1}}{L_{0}} \times 100
$$

where: $\mathrm{L}_{0}$ - initial lactose amount, $\mathrm{g} \cdot \mathrm{L}^{-1} ; \mathrm{L}_{1}-$ the amount of lactose after hydrolysis, $\mathrm{g} \cdot \mathrm{L}^{-1}$ (Vasileva et al., 2016).

Table 1. Amount of added enzymes for experimental study (mean values \pm $\operatorname{sd}(\mathrm{n}=3))$

\begin{tabular}{ccccc}
\hline Enzyme preparate & Activity & Weight, mo* & Unit \\
\hline Ha-Lactase 5200 & 5200 & $11.04 \pm 0.91$ & $57.41 \pm 5.04 \mathrm{NLU}$ \\
& $\mathrm{NLU} \cdot \mathrm{g}^{-1}$ & $52.48 \pm 2.26$ & $288.63 \pm 12.41 \mathrm{NLU}$ \\
& & $106.30 \pm 2.35$ & $584.64 \pm 12.95 \mathrm{NLU}$ \\
\hline NOLA Fit5500 & 5500 & $10.83 \pm 0.61$ & $59.56 \pm 2.26 \mathrm{BLU}$ \\
& $\mathrm{BLU} \cdot \mathrm{g}^{-1}$ & $51.30 \pm 2.00$ & $282.15 \pm 11.00 \mathrm{BLU}$ \\
& & $104.16 \pm 2.06$ & $541.61 \pm 11.37 \mathrm{BLU}$ \\
\hline \multirow{2}{*}{ GODO-YNL2 } & 5000 & $11.37 \pm 0.94$ & $56.85 \pm 5.15 \mathrm{NLU}$ \\
& $\mathrm{NLU} \cdot \mathrm{g}^{-1}$ & $51.61 \pm 1.76$ & $283.83 \pm 9.70 \mathrm{NLU}$
\end{tabular}

* was calculated for $100 \mathrm{ml}$ of whey permeates

Units of ß-galactosidase activity are defined differently by each manufacturer. BLU, bifido lactase units; NLU; neutral lactase units.

Table 2. Summary of commercial enzymes main properties

\begin{tabular}{|c|c|c|c|c|c|c|}
\hline Name & $\begin{array}{c}\text { Dosage recommendation } \\
\text { by producer }\end{array}$ & Manufacturer & Microorganism & Physical form & $\begin{array}{l}\text { Protease. } \\
\text { PU.ml-1 }\end{array}$ & Enzymatic composition \\
\hline GODO-YNL2 & $1 \mathrm{~g} \cdot 1-1$ & Danisco & Kluyveromyces lactis & Liquid & $<35$ & Lactase \\
\hline Ha-Lactase 5200 & $\begin{array}{c}500-4000 \\
N L U \cdot 1-1\end{array}$ & Chr. Hansen & Kluyveromyces lactis & Liquid & $<35$ & Lactase \\
\hline NOLA $^{\mathrm{TM}}$ Fit 5500 & $\begin{array}{c}500-18000 \\
\text { BLU·1-1 }\end{array}$ & Chr. Hansen & $\begin{array}{c}\text { Bacillus } \\
\text { licheniformis }\end{array}$ & Liquid & $<10$ & $\begin{array}{l}\text { Lactase; } \\
\text { Invertase }\left(\mathrm{U} \cdot \mathrm{ml}^{-1}\right)<0.01 ; \\
\text { Arylsulfatase }\left(\mathrm{A} 410 \cdot \mathrm{ml}^{-1}\right)<0.03 \text {; } \\
\text { Glycoamylase }\left(\mathrm{U} \cdot \mathrm{ml}^{-1}\right)<4 ; \\
\text { Lipase }\left(\mathrm{LFU} \cdot \mathrm{ml}^{-1}\right)<0.07 ; \\
\text { Cellulase }\left(\mathrm{U} \cdot \mathrm{ml}^{-1}\right)<3\end{array}$ \\
\hline
\end{tabular}

Units of $\beta$-galactosidase activity are defined differently by each manufacturer. BLU, bifido lactase units; NLU, neutral lactase units. 
High-performance liquid chromatography with refractive index detector (HPLC-RID). The amounts of lactose, glucose and galactose were determined as described by Zolnere and Ciprovica (2019). Samples were centrifuged for $5 \mathrm{~min}$ at $10000 \mathrm{rpm}$. Then $1.5 \mathrm{ml}$ of a sample was transferred into a sampler vial and sealed for HPLC analysis. HPLC (Prominence HPLC system, Shimadzu LC-20, Torrance, CA, USA) was used for sugar determination, refractive index detector RID-10A; column SUPELCOSILTM LC-NH2 (25 $\mathrm{cm} \times 4.6 \mathrm{~mm}) 5 \mu \mathrm{m}$ column; $35{ }^{\circ} \mathrm{C}$ temperature; gradient mobile phase acetonitrile: deionised water $(80: 20)$; volume of the injected sample: $10 \mu \mathrm{l}$; total analysis time $15 \mathrm{~min}$;

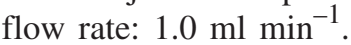

Statistical analysis. The results were expressed as mean \pm standard deviation (SD) of three replicates for sugar measurements. Statistical analyses were carried out using twofactor ANOVA and Tukey tests. Differences were considered statistically significant when $p<0.05$.

\section{RESULTS}

GY and HL enzymes contain only ß-galactosidase, while the enzyme NF contains a very small quantity of enzymes other than $ß$-galactosidase, suggesting that it can catalyse the hydrolysis of components other than lactose.

Prepared acid whey permeates with the initial lactose concentration $194.89 \pm 5.18 \mathrm{~g} \cdot \mathrm{l}^{-1}, 273.65 \pm 16.99 \mathrm{~g} \cdot \mathrm{l}^{-1}$ and $391.17 \pm 11.81 \mathrm{~g} \cdot \mathrm{l}^{-1}$ were used for 4-hour hydrolysis. Higher hydrolysis rates for the NF enzyme (Fig. 1 A) was observed at acid whey permeate solids concentration $20 \%$ and $30 \%$ using 500 units: $98.89 \pm 8.14 \%$ and $84.57 \pm$ $9.16 \%$, respectively. Statistically, no significant $(p>0.05)$ difference was found between these results. With NF en-
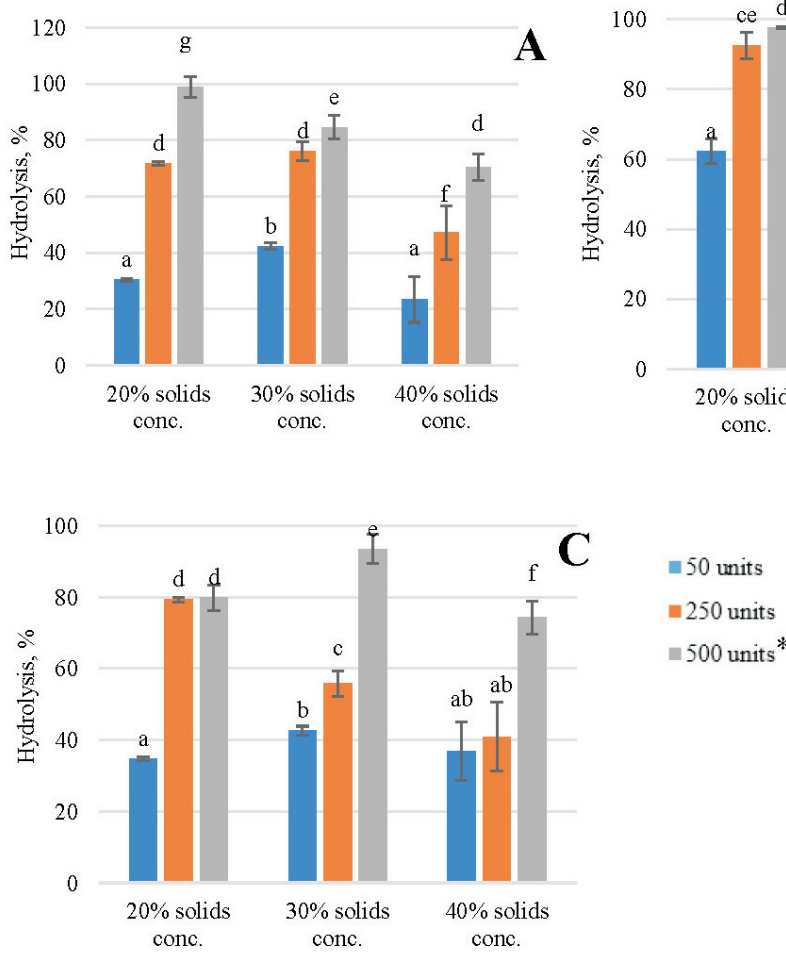

zyme dose 250 units it was possible to hydrolyse more than half $(50 \%)$ of the lactose in acid whey permeate (hydrolysis percentage range from $47.07 \pm 4.10 \%$ to $76.05 \pm 3.47 \%$ ) . No significant $(p>0.05)$ difference was observed between permeate solids concentration $20 \%$ and $30 \%$. Hydrolysis percentage of the HL enzyme (Fig. 1 B) doses at $20 \%$ and $30 \%$ permeate were not significantly different $(p>0.05)$. In the case of GY enzyme (Fig. 1 C) at doses 250 and 500 units for lactose hydrolysis, the hydrolysis percentage range was from $55.77 \pm 1.36$ to $79.80 \pm 3.31 \%$.

Prepared sweet whey permeates with initial lactose concentration $200.72 \pm 8.25 \mathrm{~g} \cdot \mathrm{l}^{-1}, 303.93 \pm 27.09 \mathrm{~g} \cdot \mathrm{l}^{-1}$ and $399.17 \pm 17.08 \mathrm{~g} \cdot \mathrm{l}^{-1}$ were used for 4-hour hydrolysis. Figure 2 illustrates similar behaviour for all enzymes. The percentage of lactose hydrolysis decreased with an increase of sweet whey permeate solids concentration. No significant differences were observed between lactose hydrolysis of permeate solids concentration $30 \%$ and $40 \%$ using 250 and 500 units of Kluyveromyces lactis enzymes (Fig. 2 B and C). The highest lactose hydrolysis for HL enzyme ranged from $77.67 \pm 1.49 \%$ to $97.95 \pm 2.00 \%$ and for GY enzyme from $50.55 \pm 0.96 \%$ to $82.34 \pm 8.00 \%$.

Tables 2 and 3 show the concentration of glucose and galactose formed during four hours of lactose hydrolysis in concentrated sweet and acid whey permeates using commercial enzymes. The monosaccharide concentration significantly differed between permeate concentrations. Addition of 50 units of enzymes to all concentrated permeates resulted in low monosaccharide formation, which was also reflected by insufficient enzyme activity. The HL enzyme showed the highest monosaccharide production capacity.

Comparing sugar profiles in Figure 3, the employed enzymes differed in formation of sugars other than lactose in

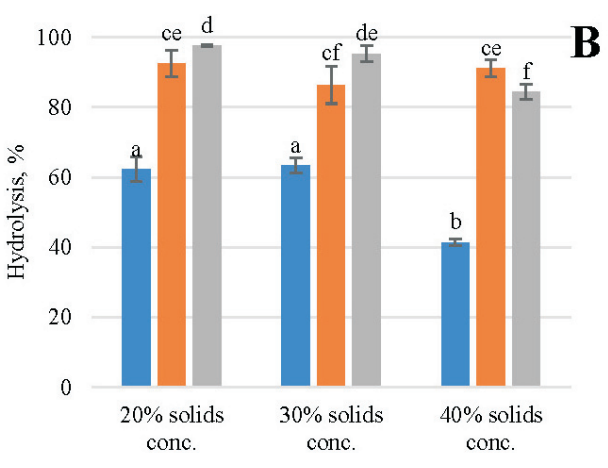

Fig. 1. Comparison of lactose hydrolysis by 3 commercial enzymes at different concentrations at various acid whey permeate solids concentration $(20 \%, 30 \%$ and $40 \%$ $\left.\mathrm{w} \cdot \mathrm{v}^{-1}\right)$. Panel A shows the hydrolysis results of enzyme NOLA Fit5500. Panel B shows the hydrolysis results of enzyme Ha-Lactase 5200. Panel C shows the hydrolysis results of enzyme GODO-YNL2.

* data on hydrolysis of lactose using 500 units of enzyme NF. HL and GY was taken from Zolnere \& Ciprovica (2019). Means followed by the same letter do not differ significantly by Tukey's test $(p>0.05)$. 

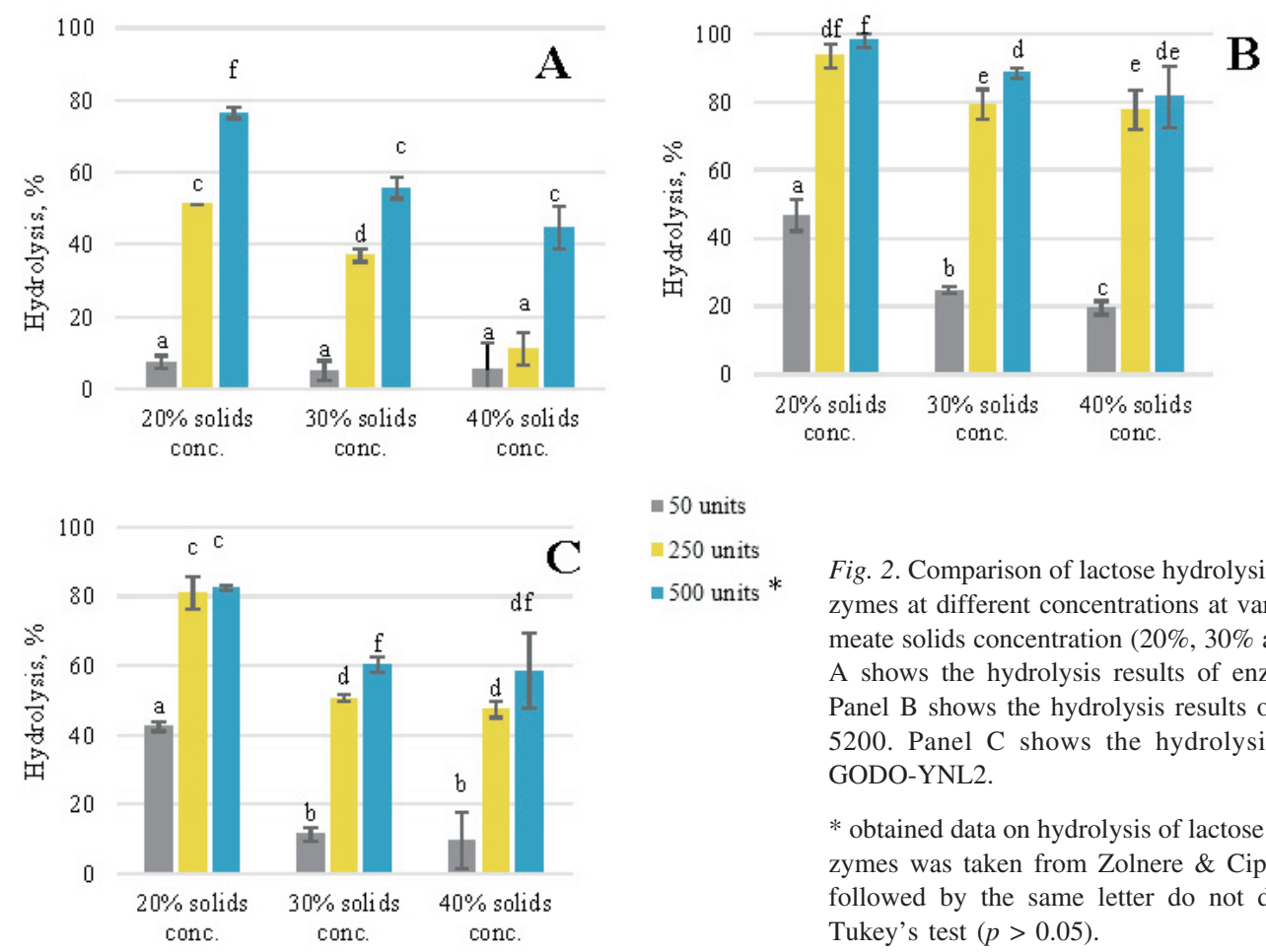

Table 3. Characteristics of acid and sweet whey

\begin{tabular}{l|c|c|c|c|c}
\hline Permeate & $\begin{array}{c}\text { Fat, } \\
\%\end{array}$ & $\begin{array}{c}\text { Proteins, } \\
\%\end{array}$ & $\begin{array}{c}\text { Lactose, } \\
\%\end{array}$ & $\begin{array}{c}\text { Total solids, } \\
\%\end{array}$ & $\mathrm{pH}$ \\
\hline Sweet whey & $<0.1$ & $0.2 \pm 0.1$ & $3.8 \pm 0.1$ & $4.6 \pm 0.1$ & $6.1 \pm 0.1$ \\
Acid whey & $<0.1$ & $0.5 \pm 0.1$ & $4.2 \pm 0.2$ & $5.2 \pm 0.2$ & $4.6 \pm 0.1$
\end{tabular}

acid whey permeates. Using 50 units of enzymes the other sugar yield ranged from 4.25 to $31.66 \%$ and 2.70 to $12.62 \%$ in acid and sweet whey permeates, respectively. The formation of other sugars using 250 units of the enzyme was in

$\approx 250$ units

500 units $*$

Fig. 2. Comparison of lactose hydrolysis by 3 commercial enzymes at different concentrations at various sweet whey permeate solids concentration $\left(20 \%, 30 \%\right.$ and $\left.40 \% \mathrm{w} \cdot \mathrm{v}^{-1}\right)$. Panel A shows the hydrolysis results of enzyme NOLA Fit5500. Panel B shows the hydrolysis results of enzyme Ha-Lactase 5200. Panel C shows the hydrolysis results of enzyme GODO-YNL2.

* obtained data on hydrolysis of lactose using 500 units of enzymes was taken from Zolnere \& Ciprovica (2019). Means followed by the same letter do not differ significantly by Tukey's test $(p>0.05)$.

the range from 2.35 to $30.30 \%$ and from 1.91 to $22.21 \%$ in acid and sweet whey permeate solutions, respectively.

\section{DISCUSSION}

One of the important factors that can significantly impact the hydrolysis reaction is the added enzyme amount, which determines the conditions which need to be set up for the reaction and also to the final sugar profile. Description of other enzymes present in the NF enzyme preparation are as
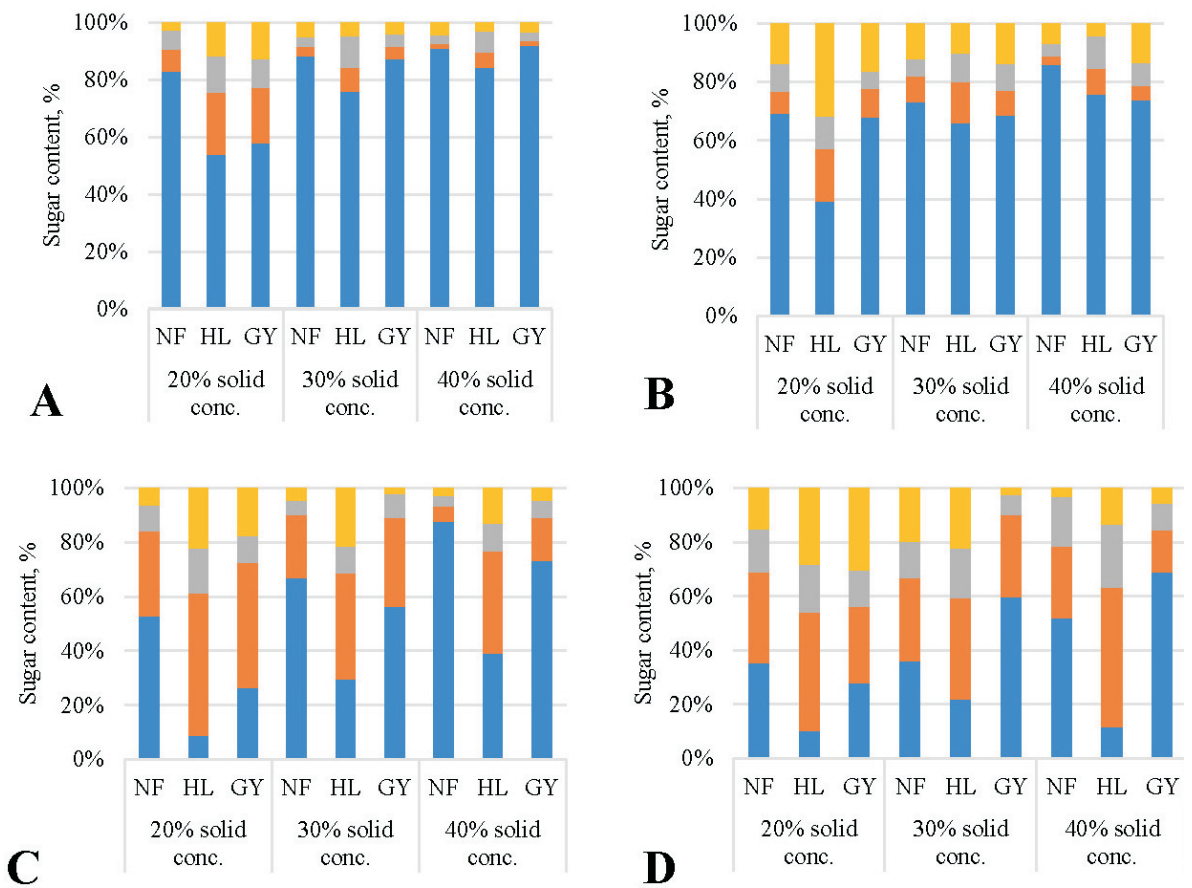

Fig. 3. Lactose conversion and galacto-oligosaccharides formation during hydrolysis of lactose in acid and sweet whey permeate solutions. Sugar profile using 50 units (A) and 250 units (C) of commercial enzymes in sweet whey permeate solutions. Sugar profile using 50 units (B) and 250 units (D) of commercial enzymes in acid whey permeate solutions. 
follows: invertase (ß-fructofuranosidase (EC.3.2.1.26)) hydrolyses sucrose into glucose and fructose (Soares et al., 2019); arylsulfatase (E.C.3.1.6.1) hydrolyses arylsulfate esters into aryl- compounds and inorganic sulphates (Wang et al., 2016); glucoamylase ( $\gamma$-amylase (EC 3.2.1.3)) hydrolyses $\alpha-1-4, \alpha-1-6$ glycosidic bonds in starch and malto-oligosaccharides (Meng et al., 2018); lipases (triacylglycerol hydrolases (E.C. 3.1.1.3)) hydrolyse many reactions such as hydrolysis or synthesis of esters, esterifications, aminations, alcoholysis, and others (Rios et al., 2018). Cellulase (endoglucanases $(\mathrm{EnG})(\mathrm{EC} 3.2 .1 .4)$ ), exoglucanases $(\mathrm{ExG})(\mathrm{EC}$ 3.2.1.94) and B-glycosidases (BG) (EC 3.2.1.21) hydrolyse $1,4-\beta$-glucosidic bonds of cellulose into smaller subunits (Sankarraj and Nallathambi, 2018). Whey passing through an ultrafiltration membrane where protein is removed, but smaller molecules such as lactose and salts pass through becoming the basis of whey permeate (Barile et al., 2009). In our study the concentration of main components of whey permeates were determined (Table 3 ). The difference of lactose concentration in permeates may be affected by the membranes used for ultrafiltration. The characteristics of whey permeate is affected by membrane pore size, equipment options and processing conditions. Moreover, each permeate was obtained from separate dairy facilities, which use different techniques and processing procedures for product production. It clearly indicates a high possibility that use of NF enzyme for lactose hydrolysis of whey permeate can result in hydrolysis of components (lipid, protein) other than lactose. These reactions would catalyse the formation of new substances, which would influence $ß$-galactosidase velocity and lactose hydrolysis efficiency.

One specific reaction conditions will not be suitable for all B-galactosidase enzymes. For instance, medium $\mathrm{pH}$ values between 2.5 and 5.4 are optimal for ß-galactosidase enzymes obtained from bacteria and are mainly used for acid whey lactose hydrolysis. In turn, medium $\mathrm{pH}$ values between 6.0 and 7.0 are optimal for B-galactosidase obtained from yeasts, which are used for milk and sweet whey lactose hydrolysis (Saqib et al., 2017). It should be noticed that substrate adjustment to enzyme optimal $\mathrm{pH}$ needs to be used for a solvent that serves as an activator for a particular enzyme and influences its velocity. Zolnere and Ciprovica (2019) reported that the major monovalent ion activator for Kluyveromyces lactis $\beta$-galactosidase is $\mathrm{K}^{+}$ion, but for $\mathrm{Ba}$ cillus licheniformis B-galactosidase $\mathrm{K}^{+}$and $\mathrm{Na}^{+}$.

Comparison of the commercial enzyme capacity to hydrolyse lactose revealed that all enzyme units have higher lactose hydrolysis potential at permeate solids concentrations of $20 \%, 30 \%$ and $40 \%\left(\mathrm{w} \cdot \mathrm{v}^{-1}\right)$ using Kluyveromyces lactis enzymes. This indicates that the permeate composition and the $\mathrm{pH}$ adjustment solution activated the enzyme of this particular species well. Rodriguez-Colinas et al. (2014) reported that lactose conversion in skimmed milk using Kluyveromyces lactis B-galactosidase (commercial preparation Lactozym pure $6500 \mathrm{~L}$ ) was obtained at a significantly high hydrolysis percentage (95\%) than for Aspergillus oryzae B-galactosidase (commercial preparation Lactase F), which showed $43 \%$ and Bacillus circulans B-galactosidase (commercial preparation Biolactase NTL-CONC) - 50\%. Also, Bacillus licheniformis ß-galactosidase lactose hydrolysis results were lower. This suggests that the process conditions may not be appropriate and need to be improved.

The experimental results were compared taking into account the final sugar profile and initial solids concentration that showed that the highest lactose hydrolysis: solids concentration $20 \%\left(\mathrm{w} \cdot \mathrm{v}^{-1}\right)$ and at enzyme 250 and 500 units for both permeates. As an exception would be HL, which showed similar results using 250 units of the enzyme in all permeate solids concentrations. According to MartínezVillaluenga et al. (2008), rapid lactose hydrolysis occurred when initial lactose concentration was 150 and $250 \mathrm{mg} \cdot \mathrm{ml}^{-1}$ using $3 \mathrm{U} \cdot \mathrm{ml}^{-1}$ of Lactozym $3000 \mathrm{~L} \mathrm{HP} \mathrm{G}$ (Kluyveromyces lactis) enzyme. Our results showed that using $20 \%\left(\mathrm{w} \cdot \mathrm{v}^{-1}\right)$ acid whey permeate as a substrate, enzymes can produce more other sugars than using sweet whey permeate. This can be explained by the addition of $\mathrm{KOH}$ solution for substrate $\mathrm{pH}$ adjustment. Our finding is also supported by the results of Rajakala \& Karthigai Selvi (2006), who reported that higher lactose hydrolysis $(86,6 \%)$ was obtained using $\mathrm{KOH}$ for whey $\mathrm{pH}$ control. Ion impact on enzyme activity is based on the ionic radius, which is tighter for $\mathrm{Na}^{+}$than for $\mathrm{K}^{+}$, and this also affects the enzyme structure. The authors recommended that $\mathrm{KOH}$ is more suitable to use for whey $\mathrm{pH}$ adjustment than $\mathrm{NaOH}$, which can inhibit $\beta$-galactosidase enzyme activity (Rajakala and Karthigai Selvi, 2006). It is important to highlight that, based on European Regulation No. 231/2012 (Anonymous, 2012), potassium hydroxide is a food additive (E525) that is safe to use it for lactose hydrolysation.

Hydrolysis results (Tables 4 and 5) showed that using 50 unit of enzymes, in many cases the amounts of glucose and galactose were more or less equal and the total amount of monosaccharides was quite low. This suggests that on an industrial scale, for production of glucose-galactose syrup for a specific permeate concentration, the concentration of enzyme needs to be increased above 50 enzyme units. Use of 250 and 500 units of enzymes resulted in high concentration of glucose and less concentration of galactose, which indicates a transgalactosylation reaction. During hydrolysis, the lactose concentration decreases and equimolar glucose and galactose concentrations develop. When the concentration of monosaccharides reaches a certain level, the production of oligosaccharides or transgalactosylation is initiated (Das et al., 2011). Other sugar molecules may be the acceptor, and then the galactose is transferred to another carbohydrate, and oligosaccharides with a higher degree of polymerisation are obtained (Otieno, 2010). This explains the occurrence of galacto-oligosaccharides during hydrolysis in our study. It should be highlighted that the high glucose concentration in the medium could be considered as an inhibitor of enzyme activity, as described in Demirhan et al., 2008 and Mano et al., 2018 reports. The amount of galacto-oligosaccharides depends on substrate type, its solids concentration and enzyme amount. 
Table 4. Monosaccharides composition using several sweet whey solids and enzyme concentrations

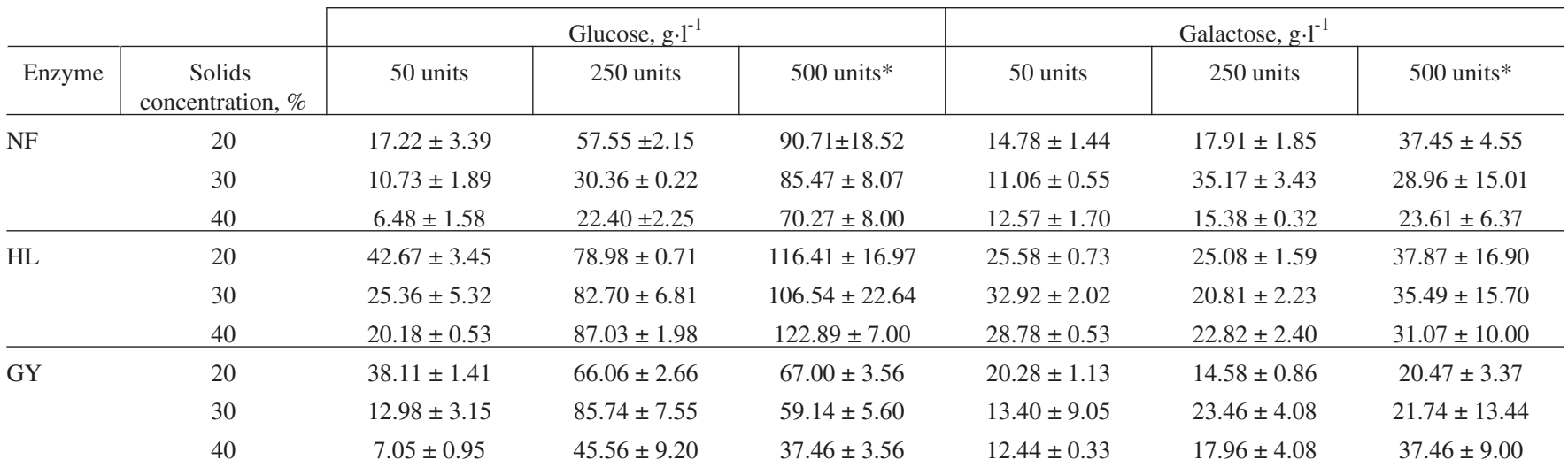

* obtained data on hydrolysis of lactose using 500 units of enzymes was taken from Zolnere and Ciprovica (2019)

Table 5. Monosaccharides composition at certain acid whey solids and enzyme concentrations

\begin{tabular}{|c|c|c|c|c|c|c|c|}
\hline \multirow[b]{2}{*}{ Enzyme } & \multirow[b]{2}{*}{$\begin{array}{c}\text { Solids } \\
\text { concentration, \% }\end{array}$} & \multicolumn{3}{|c|}{ Glucose, $\mathrm{g} \cdot \mathrm{1}^{-1}$} & \multicolumn{3}{|c|}{ Galactose, $\mathrm{g} \cdot \mathrm{l}^{-1}$} \\
\hline & & 50 units & 250 units & 500 units* & 50 units & 250 units & 500 units* \\
\hline \multirow[t]{3}{*}{ NF } & 20 & $14.89 \pm 2.47$ & $53.40 \pm 0.84$ & $65.39 \pm 9.16$ & $19.04 \pm 10.87$ & $25.74 \pm 1.32$ & $70.09 \pm 15.10$ \\
\hline & 30 & $21.06 \pm 4.17$ & $61.57 \pm 4.48$ & $53.03 \pm 16.03$ & $13.57 \pm 1.43$ & $26.87 \pm 2.11$ & $81.40 \pm 4.46$ \\
\hline & 40 & $10.89 \pm 0.97$ & $108.96 \pm 9.01$ & $73.72 \pm 9.16$ & $14.80 \pm 1.29$ & $74.45 \pm 6.48$ & $35.20 \pm 21.74$ \\
\hline \multirow[t]{3}{*}{ HL } & 20 & $33.90 \pm 4.74$ & $64.40 \pm 1.51$ & $60.56 \pm 4.88$ & $21.61 \pm 0.53$ & $25.74 \pm 0.96$ & $22.02 \pm 3.25$ \\
\hline & 30 & $23.20 \pm 7.77$ & $69.67 \pm 3.77$ & $64.81 \pm 6.54$ & $16.57 \pm 1.20$ & $34.34 \pm 1.57$ & $27.25 \pm 10.25$ \\
\hline & 40 & $26.93 \pm 2.41$ & $161.26 \pm 9.37$ & $66.61 \pm 4.88$ & $34.66 \pm 3.10$ & $72.19 \pm 6.66$ & $54.07 \pm 7.00$ \\
\hline \multirow[t]{3}{*}{ GY } & 20 & $18.80 \pm 0.24$ & $42.04 \pm 1.09$ & $51.32 \pm 7.09$ & $11.44 \pm 0.51$ & $20.22 \pm 1.68$ & $27.49 \pm 0.35$ \\
\hline & 30 & $21.15 \pm 3.77$ & $68.27 \pm 9.42$ & $56.50 \pm 0.04$ & $22.34 \pm 0.04$ & $16.42 \pm 1.03$ & $26.40 \pm 8.00$ \\
\hline & 40 & $16.67 \pm 1.73$ & $54.00 \pm 5.30$ & $45.15 \pm 7.07$ & $26.97 \pm 3.25$ & $33.75 \pm 3.29$ & $28.43 \pm 10.00$ \\
\hline
\end{tabular}

* obtained data on hydrolysis of lactose using 500 units of enzymes was taken from Zolnere and Ciprovica (2019)

The enzyme concentration is one of the critical factors to be taken into account in enzymatic hydrolysis processes, both in terms of yield and activity. It should also be considered in choice of the substrate for hydrolysis. Data from this study showed wider and more specific information of effects of both permeate concentration and as well as enzyme amount on lactose hydrolysis and glucose and galactose outcome. Sweet and acid whey permeates are suitable substrates for glucose-galactose syrup production. Comparing the two whey permeates in lactose hydrolysis, a higher percentage of hydrolysis was obtained using acid whey. The most suitable lactose hydrolysis concentration was $20 \%$ of total solids and 250 units of enzymes. Whey permeate hydrolysis into glucose - galactose syrup provides manufacturing opportunities to use whey as a valuable raw material and perspectives for whey vaporisation.

\section{ACKNOWLEDGEMENT}

The research was supported by project 'Strengthening Research Capacity in the Latvia University of Agriculture'. Contract No. 3.2.-10/2017/LLU/27. The study was supported by the Agriculture and Rural Support Service of the Republic of Latvia project No. 18-00-A01612-000012 "Novel solutions for milk products and their processing by-products production".

\section{REFERENCES}

Anonymous (2012). Commission Regulation (EU) No 231/2012. Official Journal of the European Union, 55, 1-300.

Argenta, A. B., Scheer, A. D. P. (2020). Membrane separation processes applied to whey: A Review. Food Rev. Int., 36 (5), 499-528.

Barile, D., Tao, N., Lebrilla, C. B., Coisson, J. D., Arlorio, M., German, J. B. (2009). Permeate from cheese whey ultrafiltration is a source of milk oligosaccharides. Int. Dairy J., 19 (9), 524-530.

Chandrapala, J., Chen, G. Q., Kezia, K., Bowman, E. G., Vasiljevic, T., Kentish, S. E. (2016). Removal of lactate from acid whey using nanofiltration. J. Food Eng., 177, 59-64.

Chandrapala, J., Duke, M. C., Gray, S. R., Zisu, B., Weeks, M., Palmer, M., Vasiljevic, T. (2015). Properties of acid whey as a function of $\mathrm{pH}$ and temperature. J. Dairy Sci., 98 (7), 4352-4363.

Das, R., Sen, D., Sarkar, A., Bhattacharyya, S., Bhattacharjee, C. (2011). A comparative study on the production of galacto-oligosaccharide from whey permeate in recycle membrane reactor and in enzymatic batch reactor. Ind. Eng. Chem. Res., 50 (2), 806-816.

Demirhan, I. N., Kilic, D., Ozbek, B. (2008). Product inhibition of whey lactose hydrolysis. Chem. Eng. Commun., 195 (3), 293-304.

Jurado, E., Camacho, F., Luzón, G., Vicaria, J. M. (2004). Kinetic models of activity for $\beta$-galactosidases: Influence of $\mathrm{pH}$, ionic concentration and temperature. Enzyme. Microb. Tech., 34 (1), 33-40.

Lindsay, M. J., Walker, T. W., Dumesic, J. A., Rankin, S. A., Huber, G. W. (2018). Production of monosaccharides and whey protein from acid whey waste streams in the dairy industry. Green Chem., 20 (8), 1824-1834. 
Mano, M. C. R., Paulino, B. N., Pastore, G. M. (2019). Whey permeate as the raw material in galacto-oligosaccharide synthesis using commercial enzymes. Food Res. Int., 124, 78-85.

Martínez-Villaluenga, C., Cardelle-Cobas, A., Corzo, N., Olano, A., Villamiel, M. (2008). Optimization of conditions for galactooligosaccharide synthesis during lactose hydrolysis by ß-galactosidase from Kluyveromyces lactis (Lactozym 3000 L HP G). Food Chem., 107 (1), 258-264.

Meng, H., Li, D., Zhu, C. (2018). The effect of ultrasound on the properties and conformation of glucoamylase. Int. J. Biol. Macromol., 113, 411-417.

Otieno, D. O. (2010). Synthesis of B-galactooligosaccharides from lactose using microbial ß-galactosidases. Compr. Rev. Food Sci. F, 9 (5), 471-482.

Rajakala, P., Karthigai Selvi, P. (2006). The effect of pH, temperature and alkali metal ions on the hydrolsis of whey lactose catalysed by B-galactosidase from Kluyveromyces marxianus. Int. J. Dairy Sci., 1, $167-172$.

Rios, N. S., Pinheiro, B. B., Pinheiro, M. P., Bezerra, R. M., dos Santos, J. C. S., Barros Gonçalves, L. R. (2018). Biotechnological potential of lipases from Pseudomonas: Sources, properties and applications. Process Biochem., 75, 99-120.

Rodriguez-Colinas, B., Fernandez-Arrojo, L., Ballesteros, A. O., Plou, F. J. (2014). Galactooligosaccharides formation during enzymatic hydrolysis of lactose: Towards a prebiotic-enriched milk. Food Chem., 145, 388-394.

Sady, M., Yna Jaworska, G., Grega, T., Bernas, E., Bernas, B., Domagaí, J. (2013). Application of acid whey in orange drink production. Food Technol. Biotech., 51 (2), 266-277.

Sankarraj, N., Nallathambi, G. (2018). Enzymatic biopolishing of cotton fabric with free/immobilized cellulase. Carbohydr. Polym., 191, 95-102.

Tanguya, G., Tuler-Perrone, I., Dolivet, A., Santellani, A. C., Leduc, A., Jeantet, R., Schuck, P., Gaucheron, F. (2018). Calcium citrate insolubilization drives the fouling of falling film evaporators during the concentration of hydrochloric acid whey. Food Res. Int., 116 (April), 175-183.

Sampaio, F. C., de Faria, J. T., da Silva, M. F., de Souza Oliveira, R. P., Converti, A. (2019). Cheese whey permeate fermentation by Kluyveromyces lactis: A combined approach to wastewater treatment and bioethanol production. Environ. Technol., 1-9, doi: 10.1080/09593330.2019.1604813

Saqib, S., Akram, A., Halim, S. A., Tassaduq, R. (2017). Sources of B-galactosidase and its applications in food industry. 3 Biotech, 7 (1), 1-7.

Soares, A. de S., Augusto, P. E. D., Leite Júnior, B. R. de C., Nogueira, C. A., Vieira, É. N. R., de Barros, F. A. R., Stringheta, P. C., Ramos, A. M. (2019). Ultrasound assisted enzymatic hydrolysis of sucrose catalyzed by invertase: Investigation on substrate, enzyme and kinetics parameters. LWT (Lebensmittel-Wissenschaft \& Technologie), 107, 164-170.

Vasileva, N., Ivanov, Y., Damyanova, S., Kostova, I., Godjevargova, T. (2016). Hydrolysis of whey lactose by immobilized ß-galactosidase in a bioreactor with a spirally wound membrane. Int. J. Biol. Macromol., 82, 339-346.

Wang, X., Duan, D., Fu, X. (2016). Enzymatic desulfation of the red seaweeds agar by Marinomonas arylsulfatase. Int. J. Biol. Macromol., 93, 600-608.

Wronkowska, M., Juśkiewicz, J., Zduńczyk, Z., Warechowski, J., Soral-Śmietana, M., Jadacka, M. (2018). Effect of high added-value components of acid whey on the nutritional and physiological indices of rats. $J$. Funct. Foods, 50, 63-70.

Zolnere, K., Ciprovica, I. (2019). Lactose hydrolysis in different solids content whey and milk permeates. In: Proceedings of the 13th Baltic Conference on Food Science and Technology FOODBALT 2019 joined with 5th North and East European Congress on Food NEEFood 2019, May 2-3, 2019, Jelgava, Latvia, pp. 35-39.

Received 20 May 2020

Accepted in the final form 17 June 2020

\section{LAKTOZES HIDROLĪZES APSTĀKL̨U OPTIMIZĀCIJA DAŽĀDAS SŪKALU SAUSNAS UN ß-GALAKTOZIDĀZES KONCENTRĀCIJAS IETEKMĒ}

Pētījuma mērkis bija izvērtēt, kādos apstākḷos ß-galaktozidāze (NOLA Fit5500 un Ha-Lactase 5200, Chr. HANSEN (Dānija) un GODO-YNL2, Danisco (Dānija)) spēj efektīvi hidrolizēt laktozi glikozē un galaktozē. Laktoze, glikoze un galaktoze noteikta ar HPLC-RID. Hidrolīze veikta optimālā enzīma temperatūrā $42,5^{\circ} \mathrm{C} 4$ stundas. Hidrolīzes procesa laikā vides pH tika regulēts, izmantojot $10 \% \mathrm{KOH}$. Eksperimenta rezultāti salīdzināti pēc iegūto cukuru profila un noskaidrots, ka augstākā laktozes hidrolīzes pakāpe tika sasniegta substrātiem ar sausnas saturu $20 \%\left(\mathrm{w} \cdot \mathrm{v}^{-1}\right)$, pievienojot 250 un 500 enzīma vienības. Izmantojot 50 enzīma vienības, tika iegūts praktiski vienāds glikozes un galaktozes saturs, lai gan kopējais monosaharīdu saturs bija salīdzinoši zems. Salīdzinot siera un biezpiena sūkalu fermentācijas iespējas ar ß-galaktozidāzi, augstāku laktozes hidrolīzes pakāpi var sasniegt, izmantojot tieši biezpiena sūkalas. 